\title{
2. MaXim Vinaver and the First Russian State Duma
}

The name, Maxim Vinaver, became associated with the First Russian State Duma. He wrote two books on the subject, Conflicts in the First Duma (Konflikty v pervoi Dume) (1907) and The History of the Vyborg Appeal [Memoirs] (Istoriia vyborgskogo vozzvaniia [vospominaniia]) (written in 1910 and published in 1913). This output, emerging in the years following the closure of the First Duma, memorializes the short period between spring and fall of 1906. At the same time, these two memoirs reflect the time in which they were written, and allude to new realities in Russian political life between 1906 and the First World War. They are redolent of internecine disputes within the Russian Constitutional Democratic Party (Kadet), the difficulties of organizing a unified Jewish politics, and the relentless struggle with the government.

In this essay I discuss the content of Vinaver's memoirs while trying to reconstruct the political context in which they were written. My goal is not to provide an exhaustive description of Vinaver's activities in the Duma or to provide a full description of the memoirs' content. Rather, I outline Vinaver's perception of the First Duma and illuminate the political goals contained in these two books.

Lawyer, politician, and memoirist, Maxim Vinaver was born to a middle-class Jewish family in 1862, in Warsaw. After graduating with a degree in law from the University of Warsaw, he settled in St. Petersburg, where he was active both as a trial lawyer and editor of and contributor to the most prestigious legal journals in Russia, including Iuridicheskii vestnik and Vestnik prava. Because of regulations affecting the advancement of Jewish lawyers, he was unable to rise beyond the rank of lawyer's assistant for fifteen years, until regulations were changed in $1904 .^{1}$ In St. Petersburg he was active in Jewish political circles, helping form the Defense Bureau in 1902. ${ }^{2}$ This organization was dedicated to defending Jews by non-violent means, including civil trials and the print

1 S. L. Kucherov, "Evrei v russkoi advokature," Kniga o russkom evreistve ot 1860-kh godov do revoliutsii 1917 g. (New York: Soiuz russkikh evreev, 1960), 407.

2 B. Nathans, Beyond the Pale: The Jewish Encounter with Late-Tsarist Russia (Berkeley and Los Angeles: University of California Press, 2002), 329. 
media. Early in 1905, Vinaver reacted quickly to lend support to the Revolution. In February 1905, he urged the Society for the Promotion of Enlightenment among the Jews of Russia to join the Union of Unions, and in March, he and the Jewish lawyer, Henrik Sliozberg, arranged an illegal meeting in Vilna "in order to set up an independent Jewish political organization." ${ }^{3}$ At the so-called Vilna Congress, the Union for the Attainment of Full Equality for the Jewish People in Russia (Soiuz dlia dostizheniia Polnopraviia Evreiskogo Naroda v Rossii) was founded, and soon after, it also joined the Union of Unions. In October 1905, when the Constitutional Democratic Party was established, Vinaver became one of its leaders and was elected as a representative from St. Petersburg to the First Duma.

In order to understand Vinaver's perspective on the First Duma, one has to consider his attitude toward the Revolution of 1905, the politics of the Kadet party, and his activities within the Jewish community. Of primary importance is the fact that Vinaver viewed the Kadets as the authentic heirs of the Revolution. He believed that the work of the Kadets in establishing the Union of Unions, leading the 1905 Revolution, fighting in the First Duma, and organizing the Vyborg Appeal reflected a new stage in the heroic revolutionary tradition. The right to represent the Russian people had shifted away from the radicals to the Constitutional Democrats. Moreover, unlike radicals, the Kadets adapted to the new situation and understood that with the establishment of a Duma, the methods of struggle had changed. To wrest control of political power from the tsarist government, revolutionary violence would have to cede its place to peaceful negotiation.

One reason that Vinaver wrote memoirs about the First Duma was no doubt to express disappointment. In his memoirs Vinaver remembered not only what occurred, but also the way he felt. Comparing the first efforts to scaffolding at a large building site, Vinaver writes:

When we carried out the work of the First Duma day after day, then it seemed to us only like the scaffold of a grandiose building, a scaffold that we would soon re-

3 C. Gassenschmidt, Jewish Liberal Politics in Tsarist Russia, 1900-1914: The Modernization of Russian Jewry (New York: New York University Press, 1995), 21. For more on Sliozberg, see B. Horowitz, "Henrik Sliozberg: A Mirror of Petersburg Jewry in Late Tsarist Days," in Empire Jews, 139-52. 
move, although now it has already become fossilized in memoirs as something that has receded from life's background. Is it worthwhile to print onto the memory of our descendents the outline of the scaffold, the history of the first cautious creative movements, when behind the scaffold something was hidden that would soon shine as an eternal monument to the work of the first people's democracy and, impervious to decay, would live forever? ${ }^{4}$

In the years following the closure of the Duma, when Vinaver's ideal of yoking revolutionary passion to parliamentary democracy grew further from attainment, he valorized the First Duma as reflecting a better time. In addition, Vinaver glorified the Duma for its role in advancing the political and social life of the country generally and for uniting the left and the center in the struggle against the government. In Conflicts in the First Duma, he emphasizes the Duma's significance by referring to the renunciations of its detractors.

Skeptically inclined individuals, having read the whole history of the imperceptible and controversial work to extend the life of the first Russian People's parliament and recalling that in the end the Duma did die, will turn away from our useless efforts with a disdainful smile: what good is that masterful exquisite pattern on cloth which a bayonette can rip apart with such ease? In response we quote two or three lines that belong to the leaders of the party which boycotted the Duma more vigorously than the others [Social Democrats]. "The State Duma lived only 72 days, but its role was huge in developing the struggle for freedom. The Duma pulled away the heavy curtain that hid the holy of holies of Russia's state power from the sight of the people... The Duma was a national agitator of enormous strength." 
While a reader today can understand the subjective importance of the First Duma for its participants, one hesitates to assign it major historical significance. In fact, looking back over a century later, it is easier to accept the claim that Vinaver created an idealized image that did not coincide with reality. The Kadet, Vasily Maklakov charged that, "Vinaver was not only a participant, but he preserved the ecstatic cult of the Duma. He became its singer. He illuminates with the light of dreams anything and everything connected with it." ${ }^{6}$

Vinaver's excitement can be excused. After all, a number of generations of patriotic Russians had been waiting impatiently for the chance to establish democratic institutions of government. The Duma provided the first experiment of a democratic legislature in modern Russian history. Here was the first chance to hold genuine elections, design legislation, and speak directly to the public through a relatively free press. This idea of "firsts" gripped Vinaver and other leaders in the First Duma. Pavel Miliukov has written, "M. M. Vinaver was not a professional politician. Not a single person who went into the fight for Russia's social and political liberation was one. The possibility itself of such a fight-in that constitutional context in which we found ourselves assigned to lead it-came into being so recently and suddenly that our generation could not rely on any previous experience. Our experience was the first one; we had to feel our military position on the run and learn from our own mistakes."

Besides portraying the First Duma as part of an exercise in personal accounting, Vinaver used the memoir form to express his political ideals in the context of the struggles in the years immediately following the Duma's closing. In order to understand these contexts, we must examine Vinaver's political position after 1905.

Politically, Vinaver stood on the left flank of the Kadet party. As one may recall, the groups that coalesced to become the Constitutional Democrats included leftist-leaning liberals, members of various professional unions, including the union of railroad workers and employees of the Zemstvos. The right wing consisted mainly of business leaders, many of whom left the Kadets later to form the Union of October 17,

6 V. Maklakov, “1905-1906 gody," in M. M. Vinaver i russkaia obshchestvennost' nachala XX veka (Paris: 1937), 60. See also V. Maklakov, Pervaia Gosudarstvennaia Duma, 27 aprelia-8 iiulia 1906 goda (Moscow: Tsentrpoligraf, 2006).

$7 \quad$ P. Miliukov, “Vinaver kak politik," in M. M. Vinaver i russkaia obshchestvennost' nachala XX veka, 19. 
known generally as the Octobrist party. ${ }^{8}$

Although Vinaver shared with his Kadet colleagues a respect for rule of law, he also identified with the revolutionary intelligentsia, considering its values sacred. Vinaver's sympathy for the revolutionary left was shaped by a desire for a more equitable division of resources and equal rights for all the national minorities, including Jews. In addition, he bore the tsarist bureaucracy a great deal of ill will both for personal reasons and because of its hostile treatment of Jews. In his Duma speeches, he expressed anger at the tsar's anti-terrorist campaign, the fomenting of pogroms, and the government's inability to help the peasantry with a reasonable plan for agricultural reform. ${ }^{9}$ He was disappointed in Pyotr Stolypin, whom he accused of intentionally undermining the Duma. ${ }^{10}$ St. Ivanovich and D. Zaslavsky, authors of a book on the Kadets and the Jews, described Vinaver's views accurately when they wrote, "The Constitutional Democratic Party broke with the political and social traditions of the heroic period of the Russian intelligentsia, but those traditions were still alive among Jewish liberals." ${ }^{11}$ In other words, Jews still expected the Kadets to fight for liberation even after the party had set a course of compromise with the government that did not include equal rights for Jews.

One of the central ideas of Conflicts in the First Duma was that the Kadets offered the best political leadership in the country because they alone walked the fine line between aggression and conciliation with the government, and were therefore able to nudge the government toward greater concessions. Thus, what was needed in the First Duma, according to Vinaver, was to tame the revolution and channel its energy into productive parliamentary work. With a revealing but complicated metaphor, Vinaver ends Conflicts in the First Duma this way:

Understand that these 72 days of the Duma's survival were spent largely occupied with meticulous parliamentary work. Don't reject frivolously the "fine mechanism."

8 L. Menashe, Alexander Guchkov and the Origins of the Octobrist Party: The Russian Bourgeoisie in Politics, 1905 (New York: New York University Press, 1966).

9 M. Vinaver, Rechi M. M. Vinavera (partiia narodnoi svobody) (St. Petersburg: 1907).

10 Konflikty, 182-83.

11 D. Zaslavskii and St. Ivanovich, Kadety i evrei (Petrograd, 1916), 8-9. St. Ivanovich is a pen name for Semyon Osipovich Portugeis (1880-1944), who was a well-known Menshevik. 
Realize that when you pass from fighting with a nightstick to a Mauser rifle, then you cannot jump into a fight with a rifle as though it were a nightstick. You have to use the rifle aware of all the rules of the art. You must calculate the aim in millimeters and you cannot disdainfully dispose of the fine mechanism in the middle of the fight and coarsely and senselessly wave the gun's butt around in empty space, putting your bare chest in the sights of the enemy aiming his arrow skillfully and precisely...

But all this of course only serves good cause until they take the rifle from your hands... ${ }^{12}$

The meaning of this extended metaphor refers to the conflict with the government; the image of the rifle is well chosen. Although the Kadets had chosen parliamentary methods, for Vinaver the opposition was still engaged in a lethal duel with the government. Thus he mixes metaphors, using revolutionary language to describe the mechanism of legislation, which he describes as "mundane parliamentary work" ("melkotkannaia parlamentskaia rabota"). Vinaver lauded negotiation, compromise, and tactical skill, but still he hoped to vanquish the enemy, i.e. the government. The fight continued until, as Vinaver says, your opponent "takes the rifle out of your hand,." i.e. closes the Duma. This passage sums up Vinaver's attitudes about legality, revolution, and leadership in the First Duma and the Kadet party's skills in operating their weapon.

As the largest party in the Duma, the Kadets had the main responsibility for charting strategy. ${ }^{13}$ However, not having enough seats to govern alone, they had to form a coalition with other parties. While some Kadets preferred to join with the parties of the right, Vinaver argued that one could not join hands with those who rejected equality for Jews, repudiated women's suffrage, and accepted the government's summary executions of radicals. Vinaver played an instrumental role in leading the Kadets to form a coalition with the parties on the left, such as the Trudoviki, and so-called unaligned leftists. ${ }^{14}$

Vinaver was aware of the First Duma's flaws. He lamented the way

Konflikty, 183-4.

13 The Kadets with their 180 deputies and the Trudoviki with 84 deputies commanded a majority in the parliament of 497 .

14 Konflikty, 170. 
Trudoviki and other leftists obstructed Kadet initiatives, referring as often to the fissures in the Kadet-Trudoviki bloc as to conflicts with the government. ${ }^{15} \mathrm{He}$ describes how Trudoviki used dissimulation and deceit to slow down legislation on military appropriations, agricultural reform, and even the nationalities question. He was also repelled by their public-relations campaign to denounce the Kadets and obfuscate their role. Describing the so-called Throne Speech in which Nicholas II demanded that the Duma representatives acknowledge his unconditional power, Vinaver complained about the way leftists reacted to the Kadet decision to respond without fulfilling the tsar's demand.

Our response [to the Throne Speech] served as a signal for the beginning of the attacks on our party, which continued without a break until the dissolution of the Duma and which in my opinion played a decisive role in the Duma's fate. It was only in Vyborg, at the last session of the party committees that [the attacks] were reversed with dithrymbs in praise of the party and all its Duma activities. Not only the Social Democrats and SocialistRevolutionaries, but as we will see, all the independent leftists and especially the independent leftist press participated in these attacks at the time. ${ }^{16}$

According to Vinaver, while the government bore responsibility for the Duma's closing, the failure to organize effectively lay with the leftists who, unwilling to compromise, acted arrogantly and irresponsibly. Vinaver, therefore, spoke directly in his memoirs: in elections to future parliaments, voters should shun the obstructionist left and support that party which was capable of leading the country competently and effectively, i.e. the Kadets.

Vinaver believed that the Kadets were more heroic than the radicals. In The History of the Vyborg Appeal Vinaver emphasized that the Kadets had organized the meeting of Duma deputies in Vyborg, and formulated, then proliferated the manifesto that called for civil disobedience. Moreover, in an act of self-sacrifice, the Kadets risked their own lives in order 
to save the Duma. "Distributing [the manifesto] for which we were tried and sat in prison hardly bothered us, as I said. We were entirely certain that it would get enormous distribution without any effort. And if we had realized that one needs to make an effort to distribute the farewell manifesto, we would still have chosen to do it. In reality, it turned out that we were not wrong." ${ }^{17}$

Despite the deputies' good intentions, the manifesto did not have the effect that the signatories had hoped for. When Vinaver arrived in Vyborg, the manifesto was already ready, having been written by Pavel Miliukov. Vinaver wrote:

I found the plan weakly conceived, the manifesto should have rang out the cry of rebellion more sharply; like a bolt of lightning it should have illuminated the true meaning of what had happened before the population. There wasn't any of that elemental enraged force in it. The second part-the appeal that played such a fatal role later on-did not draw any attention. It certainly seemed, especially at the first minute, that this [manifesto] was elementally the simple and natural minimum, pathetic minimum, of action that remained in our power. And exactly because it was so small we felt a special need to use decisively and boldly what was left to us: to publish our cry of rebellion which, so it seemed, corresponded to the strength of the blow that we had taken and which would gain vast momentum in the country. ${ }^{18}$

It is clear that Vinaver wanted a more vibrant document that would startle the nation with its expression of anger and frustration. Disappointed that the appeal to the population not to appear for military service was ineffective since the recruitment induction was some ten months away and the call not to pay income taxes had little relevance, since most taxes were collected from retail sales and taxes unrelated to income, Vinaver predicted that their appeal to the people would fall on

17 M. Vinaver, Istoriia vyborgskogo vozzvaniia (vospominaniia) (Moscow: 1913), 75-76.

18 Ibid., 15-16. 
deaf ears. In fact, the manifesto's publication did not lead to any displays of civic disobedience.

Inevitably, Vinaver's memoirs became involved in polemics over the memory of the First Duma that reflected internal debates within the Kadet party itself and issues related to the so-called "Jewish Question." In particular, after 1905, Vinaver became the object of criticism by Kadets on the right, such as Vasily Maklakov and Pyotr Struve, who disagreed with Vinaver's conception of a heroic Duma. ${ }^{19}$

Maklakov, for example, criticized Vinaver for refusing to recognize that the unwillingness of the leftists to cooperate with the government had caused the failure. According to Maklakov, by yielding to the demands of the leftists, Vinaver and the Kadet party had written the Duma a death sentence, unforgivably squandering a rare opportunity.

There was a total lack of understanding of one's own and the other's strengths in the First Duma. Frivolous self-assuredness, a passion for loud phrases and gestures led to contempt for real achievements. The Duma, in the words of a poet, had an aversion to "the ant-like deeds of man" and considered itself only worthy of "heroic action." The real style of the First Duma, not Vinaver's idealized one, consisted of a tense relationship of both sides. One may pity nearsighted people who because of the Duma's flaws did not perceive its qualities and were incapable of understanding the reasons for the halo that encircles it. But admiration for it should not stop one from the sad conclusion: the Duma was not appropriate for the duty assigned to it by the people's trust. One could have expected something else and something more. ${ }^{20}$

19 See also Dittmar Dahlmann, Die Provinz Waehlt: Russlands Konstitutionell-Demokratische Partei und die Dumawahlen, 1906-1912 (Koehn: Boehlau, 1996); Terence Emmons, The Formation of Political Parties and the First National Elections in Russia (Cambridge, MA: Harvard University Press, 1983); Antony Kroener, "The Debate between Miliukov and Maklakov on the Chances for Russian Liberalism," Revolutionary Russia 7, no. 2 (1994): 239-71.

20 Maklakov, "1905-1906 gody," 89. Although these remarks were published only in 1936, they represent views that Maklakov held at the time. Proof of this assertion can be found in the speeches that he gave and in his own memoirs about the period. See Rechi: Sudebnye, dumskie i publichnye lektsii, 1904-1926 (Paris: 1949); and Vlast' i obshchestvennost' na zakate staroi Rossii (vospominaniia) (Paris: 1936). 
Maklakov's disagreement with Vinaver pivoted around his interpretation of the government's intentions. ${ }^{21}$ According to Maklakov, the government was actually trying to come to an agreement with the First Duma, but had to weigh offers of compromise against the leftists' desire to spread disorder and anarchy. One can sympathize with a government that put its responsibility for domestic order above other goals. In contrast, Vinaver did not believe that the government had acted in good faith, maintaining that there was never any intention of cooperating with the Duma. In fact, government repression had actually started before October 17, 1905. The so-called "Throne Speech" and the final dispersal of the deputies served as incontrovertible proof of this claim. Convinced of the government's permanent hostility, Vinaver maintained that only a revolutionary overthrow of power would enable the Duma to wrestle power from the uncompromising government.

In fact, the two had contradictory perspectives. Whereas this was a time of tremendous positive energy and enormous potential for Vinaver, Maklakov viewed it as doomed by decadence and immorality. ${ }^{22}$

\begin{abstract}
"The style of the First Duma was not a characteristic of it or in general a characteristic of that year. It was a general phenomenon. In different doses and combinations it is the style of all those colorful, overly bright, and unhealthy epochs, which one conventionally calls "renaissances," "breaks with the past," "springs" and similar laudable names. Often the best sides of a person are revealed in these times: faith, energy, and heroism. But in these times its opposite and weaknesses are also revealed: vanity, envy, malice and most importantly, an inability to be fair, i.e. that principle quality which is taught in every political contest and which for some reason is called the "Hottentot" moral. But it is exactly these negative qualities that motivate people in dark epochs." 23
\end{abstract}

21 Georgii Adamovich, Vasilii Alekseevich Maklakov, politik, iurist, chelovek (Paris: 1959), 157-59.

22 On Maklakov's attitudes see Nikita Igorovich Dedkov, Konservativnyi liberalism Vasiliia Maklakova, (Moscow: Airo-XX, 2005); David Arwyn Davies, “V. A. Maklakov and the Problem of Russia's Western Modernization" (PhD diss., Ann Arbor, University Microfilms, 1968). 
Although one may agree with Maklakov's negative characterization of the political left, it is interesting that the perspective of those Kadets who moved to the right did not sway Vinaver, who held fast. In The History of the Vyborg Appeal, which appeared in 1913, Vinaver depicted the First Duma as a beacon of the best values, the sole institution capable of uniting the left and right, characterized by heroism and self-sacrifice. "My soul shined. The fruit of suffering and painful contemplation grew ripe. The First Duma did not dissipate without a trace. Once again it became welded into a unity that will leave the people a will and testament to the struggle for rights that have been trampled."24

Vinaver's disagreement with the Kadets on the right intensified at this time over the calls for the dominance of Russian nationalism and skepticism about Jewish equality. It is essential to know that in the Jewish political context Vinaver found himself uncomfortably positioned between individuals who were more radical on both the left and the right. In 1905, Vinaver became a leader of the Union of Equal Rights (Soiuz polnopraviia) which was composed of Jewish leaders who hoped to gain equal rights as a consequence of the Revolution of $1905 .{ }^{25}$ Soon enough, however, this coalition split into the Jewish People's Group (Evreiskaia narodnaia gruppa), which remained loyal to the liberal line, and the Jewish People's Party (Evreiskaia narodnaia partiia), which was composed of groups further to the left. In 1907, however, Vinaver's Jewish People's Group itself splintered when Zionists decided to leave to seek election to the Second Duma separately. ${ }^{26}$

Having failed to unite all the Jewish groups under the liberal banner, Vinaver faced a new threat from members of the Kadet party that had been perceived as friendly to Jews and was even called a "Jewish Party" by ultra-right groups. ${ }^{27}$ In 1909, the Kadet ideologist Pyotr Struve published an article in the liberal newspaper, Slovo (Word) entitled "Intelligentsia and the National Face" ("Intelligentsiia i natsional'noe litso") in defense of Russian nationalism and the dominance of Russian culture, raising doubts about whether Jews could be fully integrated. ${ }^{28}$ Struve

24 Vinaver, Istoriia vyborgskogo vozzvaniia, 58.

25 Gassenschmidt, Jewish Liberal Politics in Tsarist Russia, 22.

26 Ibid., 48.

27 D. C. Rawson, Russian Rightists and the Revolution of 1905 (Cambridge: Cambridge University Press, 1995), 69.

28 P. Struve, "Intelligentsiia i natsional'noe litso," in Patriotica: Politika, kul'tura, religiia, sotsialism (Moscow: Respublika, 1997), 206-8. 
made a distinction between individual Jews who joined Russian culture, whom he lauded, and Zionists and other Jewish nationalists, toward whom he was hostile.

Vinaver was critical of the article's timing since it was likely to add to the general anti-Jewish feeling that was intensifying in cultural circles due to the Chirikov Affair. Referring to Struve's comparison of the two artists, Isaac Levitan and Karl Briullov, Vinaver wrote,

In your examples Briullov is beaten by the "undilutable" Jew Levitan... Incidentally, I repeat, I understand and am inclined to respect Suzdal nationalism, but therefore I have to ask: from whom are you protecting yourself? Why have you entered into battle majestically with trumpets and banners? Why do you connect your sermon precisely with us? [...] It is a sin against truth and a particularly heavy sin because your false connection of ideas will be used maliciously to harm the weakest side. ${ }^{29}$

While Struve had been rethinking his position on the nationalities and now stood in favor of a renewed principle of state power with preferred place for the Russian people, Vinaver remained faithful to the idea of equal rights for all nationalities in a cosmopolitan rule-of-law state. ${ }^{30}$

By challenging expectations for full equality, Struve indirectly prompted Vinaver to justify his commitment to the Kadet party and explain why the Kadets should be perceived as defenders of Jewish political interests. Later Vinaver wrote a book, The Kadets and the Jewish Question (Ka-dety i evreiskii vopros), published in 1912, devoted to propagandizing the virtues of the Kadet party for Jewish voters. Alluding to objections that Kadets had not fought hard enough for Jewish rights, Vinaver recalled the days of the First Duma: "[...] Did the Kadets act correctly with regards to the Jewish people, did they do for it what they were obligated to do? To this question I answer yes unconditionally. And I am sure that

29 M. Vinaver, "Otkrytoe pis'mo P. B. Struve," in Po vekham: Sbornik statei ob intelligentsii $i$ "natsional'nom litse" (Moscow: 1909), 83-84.

30 Exactly at this time Struve was expressing ideas about the need for a great Russia. See his articles, "Velikaia Rossiia: Iz razmyshlenii o probleme russkogo mogushchestva" and "Otryvki o gosudarstve," both of which appeared in his volume, Patriotica: Politika, kul'tura, religiiia, sotsializm (1911). 
the source of accusations now falling on the Kadets are nothing but simple ignorance of the facts." ${ }^{31}$ Among the facts that people are unaware of, Vinaver points to a resolution passed by the pre-Duma Kadet congress in which the "principle of civil equality was raised as the foundation stone of the whole transformation of the state...." ${ }^{32}$ The Kadet tactics on the Jewish question was to "use the ministry's legislative proposal on freedom of conscience." "This way the Constitutional-Democrats could immediately begin to resolve the Jewish question. Since the ministry's legislative proposal removed all restrictions connected with religious confession, [it was possible] to put the Jewish question on the table and remove immediately all Jewish restrictions." ${ }^{33}$

Although many critics accused Kadets of cowardice for attempting to attain equal rights for the Jews in a "backdoor" way, i.e. by subsuming their interests in those of the whole, Vinaver was convinced of the rightfulness of this approach. Incidentally the strategy was unsuccessful; the Kadets were unable to gain increased rights for the country's Jews. Nonetheless, Vinaver defended liberals. "But I consider the unproven and unjustified accusations against the party raised in the name of the Jewish people as not just unfair, but also politically harmful. The party has up to now fulfilled and continues to fulfill its political obligations regarding the Jewish people, if not with more, than in no manner with less consistency and energy than all the other opposition parties." ${ }^{34}$

Because he was convinced that by struggling on behalf of Russian democracy he was serving Jews and by working on behalf of Jewish emancipation he was serving Russians, Vinaver was offended by Struve's remarks that revealed lines of division. Maklakov wrote, "Vinaver felt both joy and bitterness when he could speak as a representative of Judaism and a deputy from Petersburg, when he could link the fate of Judaism in Russia with the victory of the rule-of-law principle that was needed not only for them, but for everyone." ${ }^{\text {35 }}$

Incidentally, Zionists were highly critical of Vinaver, whom they accused of selling out Russia's Jews. In a number of newspaper articles,Vladimir Jabotinsky mocked Vinaver for continuing to cooper-

M. Vinaver, Ka-dety i evreiskii vopros (Odessa: 1912), 3.

Ibid., 4.

Ibid., 8.

Ibid., 9 .

“1905-1906 gody," 63-64. 
ate with the Kadets after party leaders had announced the desire to turn Russia into a nation state at the expense of the rights of its minorities. Jabotinsky wrote, "Mr. Vinaver in the same issue of Rech', March 13, 1908, nonetheless also offers for the future Jewish services warmed by mutual love, 'precisely love.' By all means. The gentle calf sucks on two teats. We grant Mr. Vinaver and the other gentle people to live Mathuselah years in that curious position where they, looking into the eyes of their 'Pan,' emotionally speak out: 'Nonetheless you love us!' But Mr. Struve and Miliukov answer, 'Mm... not really." 36

Probably because of accusations that Kadets were not doing enough to support the Jewish cause, during a conference of the Kadet Central Committee in January 1909 in Moscow, Vinaver demanded that the party make greater efforts to defend Jews. Arguing that the continuing indifference would lead to a loss of voters and serious damage to the party's reputation, Vinaver called for a change of tactics. According to Christoph Gassenschmidt, the "venture was met with success: the Central Committee of the Kadets nominated the Duma deputies [V. A.] Karaulov and [N. V.] Nekrasov to speak on behalf of the Jews in the name of the Kadet Duma faction." 37 Gassenschmidt continued, "How successful Vinaver's move was became evident in the fact that from early 1909 onwards Kadet leaders such as [F. I.] Rodichev and Maklakov not only defended Russian Jews against the right-wing anti-Semitic outbursts in the Duma, but also became active outside parliament by meeting Jewish community leaders for feedback and material to defend Russian Jewry appropriately." ${ }^{8}$

It should perhaps not come as a surprise that Vinaver introduced the Jewish question in his memoirs to underscore his conception of the unity of Russians and Jews. Heading a Duma commission to investigate the Bialystok pogrom (1905), Vinaver gave a fiery speech on June 2, 1906, in which he accused the government of instigating violence with the motivation of punishing Jews for allegedly "making the revolution." Arguing that the country had to choose between the tsarist government and the principle of rule-of-law, he pointed out that a government that wreaks violence on innocent citizens represents the antithesis of a just 
government whose function it is to protect its citizens and defend its laws. ${ }^{39}$ Vinaver ended his speech by claiming that the horror of Bialistok linked Jews to the Russian people who felt similar horror about their government. "There are few of us but we have a single enormous forcethe force of despair, and one ally - the entire Russian people filled with true humanity." 40

Although Zionist and Jewish nationalist leaders disagreed with his claim about the unity of the Jewish and Russian peoples, Vinaver did not cede on this point. Similarly, he did not yield to the contradictory views of Russian nationalists or, as we have seen, members of his own party. For Vinaver, the First Duma embodied the common cause that joined Russians with the members of all the national minorities, including Jews. ${ }^{41}$

In the years that followed the closing of the First Duma, Nicholas II changed the franchise laws, truncating the voting rights of workers and peasants in order to insure a conservative majority in subsequent Dumas. At the same time radical parties decided to participate in future elections, while the Octobrists formed their own party. The numbers of Kadets elected and their overall percentage in the Duma decreased. In an atmosphere of renewed competition between the left and right, Vinaver wanted to legitimate the Kadets as the party that embodied the proper combination of sympathy for radicalism tempered by pragmatic restraint. His memoirs about the First Duma provide a tribute to the Kadets for their unfailing attempts to "save the Duma," i.e. to save that Kadet-centered Duma capable of confrontation, idealism, heroism and self-sacrifice.

When the Provisional Government took power in 1917, Vinaver was tapped once again for his expertise, assigned to the commission for organizing the elections to the Constituent Assembly. ${ }^{42}$ After October

39 In his speech from June 26, 1906, Vinaver said, "Power that announces: I am powerless to suppress the Revolution,- - has already condemned itself to death. But the power that announces: I am powerless to openly fight with the Revolution, and therefore I will engage in hidden moves; I will distribute secret brochures, place my true state advisors, the Rachkovskys and Lavrovs, in hidden underground places and from there I will let fly poisoned arrows onto innocent people. Such a government has not only condemned itself to death, not only acknowledged itself incapable of governing, but has criminally undermined the foundation of that power which one is obligated to support." (M. Vinaver, Rechi M. M. Vinavera [partiia narodnoi svobody] [St. Petersburg, 1907], 58).

40 Ibid., 69.

41 Vinaver's Jewish identity has not been the subject of study. Suffice it to say here that a great deal more can be said on this theme than has been discussed in the context of the First Duma.

42 Vinaver's activity from 1917-1918 is described in William G. Rosenberg's Liberals in the Russian 
1917, he left Petersburg for Moscow and from there fled a Bolshevik arrest warrant. Arriving in Crimea, he joined the local anti-Bolshevik government, becoming its first Minister of Foreign Affairs. He described his Crimean experiences in Our Government: Crimean Memoirs, 1918-1919 (Nashe pravitel'stvo: Krymskie vospominaniia, 1918-1919) (1928). ${ }^{43}$

Looking back at the First Duma from the perspective of the spring of 1917, Vinaver had regrets. Relating a conversation from the spring of 1917 with the lawyer F. F. Kokoshkin, Vinaver claimed that the failed parliament in Russia was a tragedy, but less for the individual than for the country as a whole.

"We were born to be parliamentarians, but fate placed us in a situation when the struggle had to be waged by other means. That is how it's always been [how it was] in 1905-06, that's how it is now." [...] In these words told to me in one of our intimite conversations in the still early months of the Revolution, a deep tragedy in the life of this outstanding man was hidden. The tragedy here was not, however, in his personal experience; the harmony of his nature had inoculated him from any internal drama. The tragic aspect was Russia's fate that, possessing such a pearl at the dawn of its free parliamentary life, [Russia] could not take from it all its brilliance and in stupid madness allowed her [fate] to be crushed. ${ }^{44}$

That sentiment represents Vinaver's lasting view of the First Duma period. A time of amazing possibilities, the Duma changed the terrain of Russian politics, but with this change came great expectations for the attainment of participatory democracy and equality that ultimately remained unfulfilled at that time and in the intervening two decades before his death in Paris in 1926.

Revolution: The Constutional Democratic Party, 1917-1921 (Princeton: Princeton University Press, 1974).

43 A discussion of Vinaver in the Crimea can be found in Oleg Budnitskii's Russian Jews Between the Reds and the Whites, 1917-1920, trans. Timothy J. Portice (Philadelphia: University of Pennsylvania Press, 2012), 153-55.

44 Nedavnee, 135. 


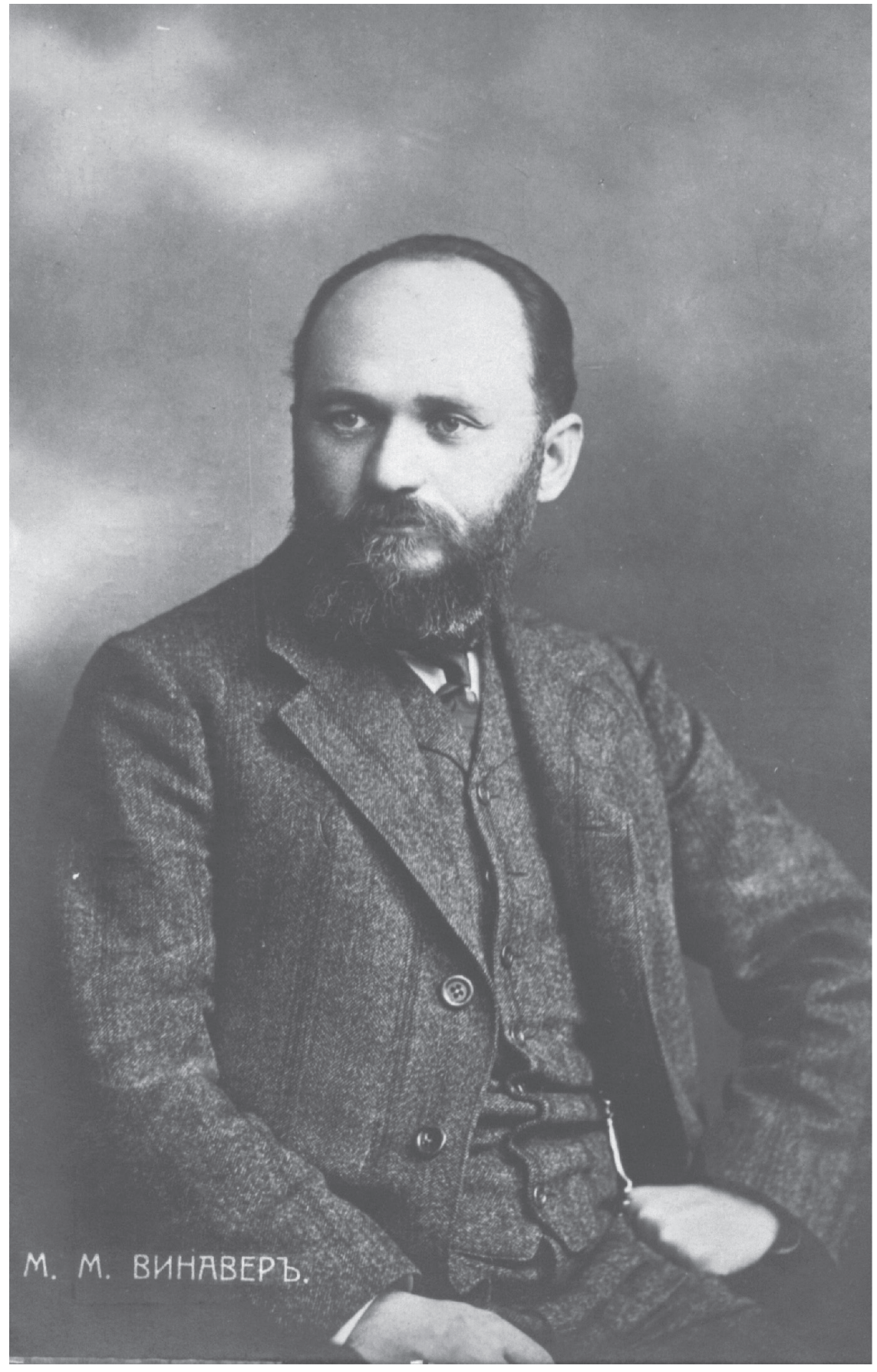

3. The lawyer and activist, Maxim Vinaver (reproduced courtesy of the Jewish Studies Department of the European University in St. Petersburg). 